\title{
Contrasting Wrongs by Privates to Keep the Market Rolling*
}

\author{
Valerio Tavormina \\ The Università Cattolica di Milano, Milan, Italy \\ Email: valerio.tavormina@tavormina-balbis.it
}

Received 28 January 2015; accepted 6 March 2015; published 11 March 2015

Copyright (C) 2015 by author and Scientific Research Publishing Inc.

This work is licensed under the Creative Commons Attribution International License (CC BY). http://creativecommons.org/licenses/by/4.0/

(c) (i) Open Access

\begin{abstract}
The market must be defended (also) against the countrymen's offenses, minimizing the costs involved and this minimization requires as a precondition the most precise possible predetermination of the offenses. The more effective regulatory device in preventing wrongs seems the threat of sanctions in excess of the redress, entrusting the decision on their application to the injured party, who should at the same time be the only entitled to reap the benefit, without distinctions between crimes and civil wrongs. The credibility of the threat, as well as any actual restauration of the harm and the prevention of reiteration, requires accuracy, speed and effectiveness in the application of sanctions and therefore: 1 ) the parties should have the duty to tell the truth and the instruments for finding the facts should be strengthened; 2) the judges' mistakes should be sanctioned as well; 3 ) the jurisdiction should be drawn so as to favor a rapid application of sanctions against an incontrovertible finding of the facts; 4) any form of penalties' remission should be subject to the consent of the injured party.
\end{abstract}

\section{Keywords}

Market's Role, Certainty of the Rules, Penalties for Unlawful Interferences, Investigative Coercion, Judicial Abuses, Delaying Justice, Nullifying the Sanctions

\section{Introduction}

\subsection{Role of the Market}

The property (i.e. an absolute reservation of use) of your own body and everything acquired through it without violating other people's property is a rule that cannot be denied without incurring a performative contradiction ${ }^{*}$ This is a translation, with some additions, of an essay published in Italian on Europa e diritto privato, 2014, 3, 847-895. I thank Enrico Co-
lombatto for his comments on the original draft of this paper. 
(Hoppe, 72 et seq. following a hint of Rothbard 1982a, 32 note 6) ${ }^{1}$ and also a criterion which minimizes conflicts for allocation of the scarce natural resources available to meet the needs felt by each one (Rothbard 1978, 33 et seq.). It follows that the voluntary (and only voluntary) circulation of individual ownership's titles of these scarce natural resources, including the bulk of said circulation, the-free-market, characterized by the exchange ${ }^{2}$, maximizes the opportunity of the individual to increase, by the use of said resources, the satisfaction of his needs ${ }^{3}$. It does so also through the prices' formation, which-by definition-records the spontaneous adhesion of all the participants in each "transaction", and through the incentive to a continuous discovery of new products and production processes (von Mises 1949, 229 et seq.; Rothbard 1962, 233 et seq.; Colombatto 2014b, 17 et seq.; etc.).

The actual satisfaction to the fullest possible extent of individual needs demands, of course, not only the availability of resources that the individual sees fit, but also their technical suitability for such satisfaction, the knowledge of which can, however, also be acquired through the said voluntary circulation of property titles (in particular: technical knowledge), whose efficiency is therefore given $a$ priori ${ }^{4}$.

The voluntary circulation in speech (which from now on-for simplicity-I will call also market) can be prevented by a violent (in the sense that the will of others is disregarded) intervention:

a) of the government (in the broadest sense), which legitimizes itself on the basis of the law system founding it and which steps in not only in the various forms of binary (taxation ${ }^{5}$, public spending etc.) and triangular (price controls, production etc.) intervention widely examined by Rothbard (1962, 875 et seq.), but also through the repression of behaviors which in themselves have nothing to do with the circulation of goods, but whose repression entails a violent dispossession to the detriment of the agent (for example, fines and imprisonment for opinion crimes etc. $\left.{ }^{\text {5bis }}\right)^{\text {5ter }}$;

b) of individuals through behaviors which the same law system that grounds the government bans and therefore qualifies illegal reconnecting to them several consequences.

\subsection{Aim of the Study}

This study is aimed at evaluating the adequacy of some of these latter provisions (and their conceivable variants) to prevent and, if necessary, to minimize the effects of interferences sub b), taking into account the reliance that private individuals may place on them (certainty of the rules), their abstract greater or lesser suitability for preventing and, if necessary, minimizing the effects of other people's illicit interferences, the rules concerning their application.

Now, the same definition of the system meeting the needs above adhered to entails that wrongful interferences by privates (to say nothing of those sub a), as well as the cost involved to prevent or minimize their effects,

\footnotetext{
${ }^{1}$ How did e.g. Beccaria, 85, in defining property as a "terrible, and perhaps unnecessary right”, but using the brain and hand in his... property (and causing the collateral damage of a river of words spent on the "terrible right").

${ }^{2}$ Catallactics, or exchange (with Greek etymon); term first used by Whately, 6, to designate the science of exchanges, as noted von Mises 1949, 3 note 2.

The remaining part is constituted by gifts which, together with any other assignment over the level that, in similar conditions, the same agent applies in favor of other subjects, represent a satisfaction of the generosity need of the same agent i.e. his consumption (von Mises 1949, 241); therefore, in a broad sense, they too are included in the exchanges.

${ }^{3}$ Including those of the spirit, as the critics of capitalism continue to forget (Rothbard 1970, 1321 et seq.; Galles).

Or, if you will, it can never be determined in its entirety, but emerges for each of its participants (as theorized Hoppe, 99 et seq. and Perkerson lately summed up very well, even without quoting Rothbard 1956, 249 et seq., the latter being criticized by Cordato, 40 et seq., but effectively defended by Gordon, 103 et seq.).

${ }^{4}$ The most brutal among the government interferences, as it consists in the direct appropriation and in the sure entire—or at least partial— destruction of others' property (in 1850 Bastiat, 130, asked the people: "will you ever understand that the State cannot do anything but giving you with a hand a bit less [what an optimist!] of what it asked you with the other hand?”; see also McBride). It is therefore totally unjustified, especially since it has been repeated after the beginning of Second World War, Einaudi's vibrant argument (199: "what would men be without State? Miserable barbarians, rambling on earth without defense against feral animals, uncertain of food and life, armed against one another"), even if laudably oriented to contrast the absurdity of a differentiated burden (the imposition) compared to a distribution which is equal for everybody (the services provided for by State, 200; such absurdity was already enlightened, for instance, by Nock 1948, 5): we only miss the last step that is the privatization of such services, since he hoped for a cyclical appearance of boni viri and was rightly skeptical on social contracts and constitutional solutions.

${ }^{5 b i s}$ These behaviors aim to change the opinion of third parties (for example denigrating the services that can be rendered by someone, whose economic expectations are worsenred, although his property is not invaded) and that are deemed illegal by the State, which however does not hesitate to violently prevent the fulfillment of other various needs (see text sub a).

${ }^{5 \text { ter }}$ And yet, there is an incredible abundance of morons, demagogues, parasites and cowards (it is difficult to quantify the respective percentages) who keep speaking of unbridled freedom of the market over the last thirty years. Nevertheless their actions aimed at satisfying their own needs belong like any other to the economic activity to be investigated.
} 
cannot be considered as its inefficiencies or failures (more than the sins of the individual can be considered defects of an ethic order: Eabrasu, 8 et seq.), but rather violent curtailments of its extension induced $a b$ externo ${ }^{6}$. And given the assumptions, the best that the Institutional context could do to counter them, would be once again to allow the free circulation of resources and the market to operate through the use or non-use of part of the same available resources in preventing or repairing such wrongful interferences (for example, buying safes to prevent theft and/or insuring the event of thefts, buying security services etc.: cf. already de Molinari, X; Tandy, 62 et seq.; Rothbard, 1978, 268 et seq.; Hoppe, 119 et seq.; and then, for a justification of justice's entrepreneurship, Smith, 409 et seq.): free circulation of resources and market defend (i.e. keep rolling and repair) themselves, if the inviolability of property acquired without violating that of others-which we were speaking of sub 1.1-is raised to the only legal rule (thereby exhausting the institutional context, which then does not need public apparatuses, taxation etc.) (Hoppe, 97 et seq.).

All the above already puts a parameter for the evaluations of law provisions that will be tested, and of the alternatives which will be envisaged, i.e. the greater or lesser distance between the results we may conceive of and those which would have occurred lacking any interference to be countered, that is the undisturbed realization of anybody's plan, voluntarily acting through available resources (Cordato, 69).

\section{Market and Certainty of the Rules for the Definition of Wrongful Interference}

\subsection{Certainty of the Rules in General}

Lacking, although only between individuals, that utmost simplification of the rules that has been envisaged in the previous $\S 1$, it would be at least necessary that the identification, prevention and prosecution of unlawful interferences of individuals ( $\$ 1.1$, lett. b) was an at least constant in time, univocally formulated, consonantly and uniformly applied object of rules, notwithstanding their whimsical design by the government. Only under these conditions the acting man, that is who pursues the satisfaction of his needs, is enabled to do it, that means knowing what resources he may use to satisfy himself or at least what a surrogate (of resources or need's satisfaction) he will be reasonably able to attain.

\subsection{A Sample of Statutory Uncertainty}

And instead, lacking for instance in our legal system provisions on compensation for violation of possession per se (i.e., regardless of ownership), it is frequently adjudged that the damaged holder is entitled to compensation, without having to prove that he also owns (or that he already compensated the owner) ${ }^{7}$, although sometimes it has been stated the opposite ${ }^{8}$.

The consequence is that this uncertainty limits the usefulness of exploiting resources in others' property: the good's utility for the potential lessee, renter, tenant, or bailee will be decreased from having to take into account the potential negative outcome of litigation resulting from a third party hypothetically and unlawfully damaging or destructing said good, while he will remain liable toward the owner; and even if the owner does not care for the good, its use will actually result less fruitful than it could have been if the rule of damages recoverability by the holder had been spelled out.

\subsection{A Sample of Judicially Induced Uncertainty}

The need for certainty is equally strong in the face of that statements that, pretending to allot "the burden of proof," smuggle the rewriting of the rules.

The problem is simple: if, in a lawsuit, Tom wants something from Dick, which facts have to emerge for pronouncing in favour of Tom? Evidently those required by law (we name them constitutive), which law at the same time, however, provides that if other facts emerge too (which we name impeditive, modificative, extinctive i.e. summarizing-preclusive), then Tom is wrong.

Now, if in deciding the court also requires, under penalty of stating against Tom, the demonstration of the opposite of (i.e. a fact incompatible with) a preclusive fact, in addition to the demonstration of the constitutive facts, it is said that the court is ill distributing the burden of proof, displacing it from Dick on Tom, as if it was a "simple" misgovernment of the proceedings. And it is therefrom inferred (e.g. art. 370, §1 of the new Brazilian

${ }^{6}$ Rightly observes therefore Colombatto 2011 (114 s.) that the costs mentioned above do not represent the costs of the exchange (circulation) but institutional costs and thus institutional and not market inefficiencies.

${ }^{7}$ Cass. civ., III Sect., 12/10/2010, n. 21011.

${ }^{8}$ Cass. civ., III Sect., 26/10/2009, n. 22602. For a further discussion, see Tavormina 2011, 390 et seq. and Fornaciari. 
code of civil procedure, definitively approved by the Brazilian Senate on 17.12.2014 and waiting for enactment) that, without prejudice of the general rule, the court might, however, deviate from it due to reasons of substantial justice, taking into account the peculiarities of the specific case.

Thus, however, the rules are rewritten when the game is already ended, because Tom, who relied on the acquisition of a right with related conditions he got evidence of, may then see his right denied by failing to prove the opposite of a fact he had no reason to look for when acquiring the right. For instance, a worker who does not print the invoices loaded into the computer system is liable for damages accrued to the employer if, according to the general rule set out in art. 1218 c.c., it does not emerge that, absent any negligence from him, it has been impossible to print them ${ }^{9}$; yet, the damages resulting from the defective layout of "Mickey Mouse" would have been denied to another employer (had he requested them) if, at the time of the decision, it did not result that the employee who loaded the presses had not been diligent ${ }^{10}$ (however, the employer should have been warned of the possibility of this outcome in advance, in order to assess, by comparing costs and benefits, whether and how much to intensify controls on the diligence of employees).

Therefore, even here (as in the case sub 2.2) higher costs (absolute and relative to other economic agents) will be determined from the unforeseen loss of resources; or else, from their deliberate and precautionary destination to cover the risk of a sudden alteration of the most reliable meaning of the law's wording; and in each case (legal costs) from the need to predict as many imaginable solutions possible and to achieve some stabilization of one of them.

\subsection{A Tool to Curb the Uncertainty of the Rules}

Outside the yet existing cases of continuous regulatory changes, as I said sub 2.1 the uncertainty of protection against others' undue interference might be significantly limited, notwithstanding the flawed formulation and the misunderstandings of the rules' meaning, by imposing on anybody appointed to apply the laws to stick to whichever meaning of them at least by some continuity (misera servitus est, ubi jus est vagum aut incertum, remembered for example Coke, XII, 49, 53, 56).

It has always been rejoined that the centuries are full of failed attempts in this direction: to remember some of them, from Justinian's prohibition to gloss and construe the Corpus iuris ("ne verbositas eorum [interpreters] aliquid legibus nostris adferat ex confusione dedecus" ${ }^{, 1}$ ), turning instead to him for any doubt ${ }^{12}$, to the common law's principle of stare decisis, to the establishment of the Cassation as the guardian of the laws etc.; and the "weak thought" even today is pleased to highlight how the optimistic forecasts of the Enlightenment have proved delusions.

However, it is undeniable that every step in this direction may reduce, a lot or a little, in any case without cost, the induced inefficiencies. And to those who wish to recognize a cost in the mortification of the judge's creativity in interpretation or in the risks of laws' sclerosis, it would not be hard to replicate that changes cautiously introduced by statute, or even in the process of interpretation, but only by a majority or by the top members of the judicial power, in order to bind all the others, are envisaged the most appropriate to the task ${ }^{13}$.

After a drastic reduction in the number of members of the Supreme Court (half-a-score at most), to facilitate

${ }^{9}$ Cass. civ., Labor Sec., 21/08/2004, n. 16530.

${ }^{10}$ Cass. civ., Labor Sec., 02/02/2002, n. 1365.

${ }^{11}$ These are the prophetic words of the constitution Tanta, §21.

${ }^{12}$ Constitution Tanta, §18, with an attempt later repeated for example by Louis XIV (tit. I, art. 7, of the so-called Code Louis namely the Ordinance on Civil Procedure of 1667), by Frederick the Great with the establishment of the Gesetzkommission (tit. XIII, §7 of the AGO 1781) by the French constituent assembly with art. 12 tit. II of the Act 16.8.1790 and art. 21 of the Decree 27.11/1.12.1790 establishing the Cassation Court.

${ }^{13}$ Beccaria, 26-28: "Who will be therefore entitled to construe the law? The sovereign, that is the depositary of the present will of all, or the judge, whose office is just to look, if such a man did or did not commit an action contrary to the laws! ... There is nothing more dangerous than the common axiom that one must look at the spirit of the law. This is a dam broken to the stream of opinions... Each man has its own point of view, each man in different times has thereof a different one. The spirit of the law would be therefore the result of a good or bad logic of a judge, of an easy or ill digestion; it would depend on the violence of his passions, on the weakness of those who suffer, on the judge's relationships with the harmed, and on all those minimal forces floating in the soul of man, that change the appearances of each object. Hence we see the fate of a citizen to change often in his passage through the various jurisdictions, and the lives of wretches being victim of false reasonings, or of the current ferment of the humors of a judge, who takes for lawful construction the vague result of all that confusing series of notions, that moves his mind. So we see the same crimes punished differently by the same court at different times, for not having consulted the constant and fixed voice of the law, but the wandering instability of constructions. A disorder, which stems from the strict observance of the letter of a criminal statute is not to be put in comparison with disorders that arise from a construction. Such a momentary inconvenience pushes to do the easy and necessary correction to the words of the law, which are the cause of the uncertainty; but it prevents the fatal license to reason, which creates the arbitrary and venal disputes." 
as much as possible a convergence of views, and after a subsequent reduction of their tasks, allowing the same court to accept only those appeals it thinks showing a question of law of particular importance ${ }^{14}$, it would thus be definitely worth:

a) to draw inspiration from the saisine pour avis provided for under art. L441-1 et seq. of the French code on the judiciary organization, to introduce the possibility, in case of enactment of a new provision, not only for the judges called to interpret the same (as in France), but also for individuals, to request the binding (unlike in France) opinion of the Court, in order to avoid that this opinion arrives only after many years (i.e., in an appeal of the decision of a lower court that has solved years after a lawsuit, in turn arisen years after the new statute) at the cost of upsetting arrangements based on a later disproven construction;

b) to introduce, as already foreseen in Brazil for the only Federal Supreme Court (and thus only for constitutional matters $)^{15}$ and newly enacted for all the civil courts ${ }^{16}$, the constraint of any judicial body to the predominant orientation of the higher grade bodies and, lacking such an orientation, to its own orientation already formed or that may be introduced and modified with a qualified majority of its members;

c) to introduce coordinating rules for the event of a conflict between binding orientations of equal grade bodies;

d) to introduce, in the wake of the German model-proceedings on disputes concerning the public offering of securities, recently revived and generalized in the new Brazilian code of civil procedure ${ }^{17}$, the remittal to an higher judiciary body of the decisions on questions of law which are common to a plurality of proceedings in progress, with the temporary suspension of the same and the subsequent constraint to the decision of the higher body;

e) to provide that any change of binding orientations applies only to events that occurred subsequently.

Naturally, it can always happen that the so introduced constraints are then not in fact respected by some judges; in any case, it will not be a lottery anymore, rather only wrongs to be prevented or remedied (infra, §5).

\section{Function, Type, Availability and Amount of the Penalty for Another's Unlawful Interference}

\subsection{Preventing and Restoring the Harm Induced by Unlawful Interference}

If, as previously mentioned (§1), (free) market, i.e. efficiency, is given through undisturbed realization of one’s plans, voluntarily acting through available resources, efficiency (i.e. market) suggests to counter others' wrongful interferences by measures (penalties) capable of preventing them or, in case of failure, at least (and better, too) of quickly restoring - as far as possible - the necessary conditions for the realization of those plans.

As was also indicated (\$1.2), this prevention can be implemented (as well as trying to train ${ }^{18}$ thereto, that "the lights accompany freedom,” as Beccaria, 157 hoped) also by technical means that would impede the unwanted event: it has been said of safes to make theft more difficult, but we can also consider controls for access to any place, that would intercept weapons and anything else one can imagine as well as an endless array of other measures for the prevention of the most various offenses.

On the one hand, however, this measures cannot guarantee the result sought and, on the other hand, they incur costs that not everyone is willing to, or capable of bearing. Thus, again as part of the prevention, a role of paramount importance is played by the threat of a penalty predictably likely to deter the abovementioned interferences (a function which can be defined as "generic prevention") and to prevent further interferences by those who have already committed one in the past (a function which can be defined as "prevention of reiteration") ${ }^{19}$.

However, since experience shows that no penalty has an absolute deterrent effect, and also that deterrence is

\footnotetext{
${ }^{14}$ What would be possible in Italy even without any constitutional change, because art. 111, paragraph 7, says that the appeal in Cassation "is always admitted" not that "it is always decided."

${ }^{15}$ Art. 103-A of the constitution. Several provisions of the civil procedure code still in force regarding appeal exclude however follow up on appeals against decisions that conform to previous judgments of the court where the appeal is filed or of higher courts (art. $518 \S 1^{\circ}, 527$ and 557), as later partially occurred even in Italy in 2009 for the appeal in Cassation (art. 360bis c.p.c.) and in 2012 for the ordinary appeal (art. 348bis c.p.c.)

${ }^{16}$ Art. 520-522 of the aforementioned new civil procedure code (these numbers are those of the second-last approved text). The reasons for consent to this solution (welcomed as "um dos principais pontos positivos do NCPC" by Dellore, Novo CPC: 5 anos de tramitação e 20 inovações, 29.12.2014, viii, available at http://jota.info/novo-cpc) have been very effectively expressed by Arruda Alvim Wambier, 3 et seq.

${ }^{17}$ Art. 973-979.

${ }^{18}$ This, as opposed to educating, can be tried with anyone who is not an idiot, as said well Nock, 1943, 89.

${ }^{19}$ Beccaria, 52: 'the end (of the penalties' enforcement) therefore is nothing else but preventing the offender from doing any further damage to his citizens, and dissuading others from doing the same": there is just to add the removal—as far as possible—of the damage already done.
} 
enhanced only if the penalties are actually applied when necessary (Beccaria, 96 et seq.; Benson, 53), it is necessary to provide for the event that prevention does not succeed: including, as just mentioned, the application of the sanction, but also, as mentioned above, prompt restoration— to the maximum possible extent—of necessary conditions for the realization of the plans altered by unlawful interferences.

Now, if both of these requirements are essential, it is convenient that they coincide or at least that they are harmonized, not only to save utterances of rules (which would be a modest saving), but above all to prevent them from interfering with each other, weakening the one (penalty) or the other (restoration).

We must then first ask whether and to what extent, the compulsion to prompt restoration of the necessary conditions for the realization of the plans altered by others' unlawful interference can also perform a function of prevention, generic and of reiteration, because, to the same extent, the problem just put at issue could find immediate solution as restoration would suffice.

\subsection{Preventing by Restoring?}

To answer the question just asked we first need to ask ourselves what this restoration consists or could consists of. Current law provisions, both in the historically younger sector of public prosecution and in the first-born civil (or privates') order, entitle the person offended by a crime or harmed by another's even merely civil wrong (as the breach of an obligation by law or contract or as a tort) that the author of such a behavior, and sometimes even a third party, accountable together with the author, at their expenses and as far as possible in kind, bring about the situation that would have been produced in the absence of the offense, if this did consist in an omission or restore the previous situation should the offense consist in its alteration ${ }^{20}$.

In case of total or partial impossibility of such a restitution in kind and anyway against its delay, it is provided for the injured person to receive the market price of the goods' lost portion (inclusive of the possibility of using its own or others' body) and/or not acquired as a result of the offense; and for the goods for whose use a market price cannot be found or is not considered appropriate ${ }^{21}$, such as certain aspects of its own physical integrity, the absence of mental suffering, and so on, monetary compensation fixed by the court by way of equity (so-called non-pecuniary and moral damage) is granted ${ }^{22}$.

This system of "civil restauration", however, is first of all very little deterrent, because it results essentially in the possibility for anyone intending to commit an offense, to compulsorily "acquire" others' goods and then proceed as in any ordinary transaction (Hoppe, 114).

Furthermore, the few elements of deterrence although present (for example, the uncertainty on the use of the damaged or destroyed asset pursued by the victim, which may be very costly to make possible anew, or even damages provided for in case of just negligent behavior) are strongly reduced by a number of additional provisions which exclude, inter alia, in the event of just negligent breach of an obligation, the recoverability of damages which were not foreseeable at the time the obligation arose (art. 1225 c.c., art. 74 of the Vienna convention on the international sale of goods, art. 7.7.4 of the Unidroit Principles, etc. ${ }^{23}$ ); that exclude the restoration of the status quo antea, if it would be too burdensome for the offender (art. 2058.2 c.c., §251.2 German c.c., art. 10:104 PETL etc.); limiting to the cases specifically provided for by statutes the recoverability of so-called "non-pecuniary" damages (art. 2059 c.c.) $)^{24}$, and so on.

\footnotetext{
${ }^{20}$ Art. 185 of our criminal code states: "Each crime entails restitution according to the civil laws. Each crime, which has caused a pecuniary or non-pecuniary damage, obliges to reparation the culprit and the people who, according to the civil laws, are liable for his action.”

${ }^{21}$ On the functional limits of market prices cf. for example von Mises 1949, 214 et seq.

${ }^{22}$ For the clarity of the wording, reference may be made to $\$ \S 249$ et seq. of the German civil code. In the Italian judicial practice these equitable compensations are relatively modest and often insignificant.

${ }^{23} \mathrm{~A}$ provision of this kind has been inserted, with the art. 3:201(a), even in the Principles of European tort law (PETL) elaborated by the European group on tort law: in other words, even if there is no pre-existing contractual relationship, and then the prospective damaged has no reason to take into account an offense from a counterparty that is not there yet, anyone would be authorized by committing an unlawful act to his detriment, to limit the compensation payable by him to a reasonably predictable amount (a real incentive to delinquent behavior, aggravated by a provision of damage's reduction if, however, "in light of the financial situation of the parties, full compensation would be an oppressive burden to the defendant”: art. 10:401).

${ }^{24}$ Limitation by which judges tend to break free "to fill the gaps in the compensatory protection of the person, which has to be ascribed to the bipolar system of pecuniary and non-pecuniary damage, the latter including the biological damage in the strict sense (configurable only when there is a lesion of the psychophysical integrity-according to the standards set by medical science), the subjective moral damage as traditionally understood (the scope of which remains exclusively that proper of the mere mental suffering and worry of mind) as well as the different and further prejudices, as long as constituting a consequence of the lesion of an interest of constitutional rank pertinent to the person. In this perspective, under art. 2059 c.c. find their place and protection all the subjective conditions related to non-pecuniary losses suffered by the person, due to torts giving rise to undue harm or due to injuring values constitutionally protected or specially uphold by particular laws” (so, recently, Cass. civ., I Sect., 20/06/2013, n. 15481, at point 6.1 of the reasons).
} 
Nor is an effective redress ensured. In fact, as it has been made clear since Condillac (53 et seq., unfairly criticized by Bastiat, 101 et seq. ${ }^{25}$ ) and then (without even quoting him: Rothbard 1995, I, 410 et seq.) by the marginalists at the end of the $800^{26}$, after about 21 centuries of Aristotelian fallacy, voluntary exchange entails an opposite inequality in (subjective) utility assessment for both parties which makes it possible ${ }^{27}$ : the market price, for him who pays, has an utility by definition lower than the purchased asset (should the utility be even equal, the buyer would have no reason to buy), while for him who receives it has an utility greater than what is sold (should this have an even equal utility, the seller would have no reason to sell) ${ }^{28}$.

On the contrary, in case of a wrong, while the wrongdoer, as long as the wrong is intentional, fully achieves his profit even paying the market price (otherwise it would not have brought himself committing the offense) (Hoppe, 114), the injured person must settle for the market price, even if the retention or acquisition, as appropriate, of (part of) the lost assets is more useful to him than that price, which in fact he did not previously want to realize and which cannot always be used to repurchase the lost assets (however after a lapse, also very important, of time, certainly not compensated by the surrogates, such as interest etc. $)^{29}$.

Ultimately, market price compensation while does not discourage wrongdoers, but rewards among them the ones who willfully violate the rights of others and does not disincentive enough, as we have already said, other wrongs causing harm, often penalizes the victim of the offense.

Prevention, and restoration would be unquestionably enhanced if the framework just outlined was instead modified providing for unconditioned restoration of the status quo antea of the harmed:

-in kind and at the expense of the offended, as far as possible;

-or, at the option of the aggrieved party, in cash equivalent;

-and always in cash equivalent to the extent not possible in kind in any event;

-increasing the cash equivalent of the market price of whatever subtracted (in a broad sense ${ }^{30}$ ) to the harmed, to compensate him for any definitively lost utility (also due to the mere lapse of time) and thus preventing the expropriation of this greater utility to the benefit of the intentional tortfeasor;

-setting minima high enough to compensate for loss (always in the broadest sense) of assets for which no market price is detected;

-with unlimited recovery of all kinds of costs (to be quantified as above) incurred by the injured person to recover compensation ${ }^{31}$.

A more accurate compensation for the damage actually borne would be so certainly achieved, and this would already by itself raise the prevention's level against committing and reiterating offenses, given the undoubted greater deterrence (Benson, 234 et seq.).

\subsection{Higher Sanctions' Aftermath on the Market}

The level of prevention, of which it has just been said, is however much higher today, due to the universal provision of (further) sanctions, both pecuniary (for the benefit of the injured person or public authority) and of

\footnotetext{
${ }^{25}$ That the exchange is made possible by the higher (subjective) utility that under the division of labor (but also the scarcity of resources in itself: Bastiat, 152 et seq., 341 et seq., 434 et seq.) each of the two traded goods assumes to the other party than the one to be surrendered, does not exclude that this opposite inequality in (subjective) utility assessment for both parties had not been previously noticed by those who had analyzed the event.

${ }^{26}$ Menger, 158; Jevons, 138.

${ }^{27}$ Rothbard 1995, I, 16 et seq. ; Colombatto 2014b, 18 et seq. A few years before Condillac, Turgot had also noticed it (89 et seq.), although then proceeded to an illogical (lacking any possibility of measuring and any realism of required conditions) conversion of the difference of valeur estimative (equal for both parties in absolute terms, although algebraically opposite: 91) into an equality of valeur exchangeable or appreciative (91 et seq.), reachable through a tight bargaining between the parties (90 et seq.).

${ }^{28}$ Hence the absurdity of formulas such as, for example, “disproportion” between the assets or services exchanged (art. 1448.1 c.c., art. 67.1, n. 1 l.f., etc.), as if the one could be gauged in terms of the other (cf. infra text and notes 32 and 37); and instead the appropriateness of referring oneself to the interest of a party to the performance of the other (e.g., art. 1464 c.c.).

Art. 10:201 PETL opposes determining the damage concretely, always to be preferred, to determining it abstractly, "for example, in reference to a market value."

${ }^{29}$ Therefore it makes no sense, if not as an abstraction, to argue on social costs and neutrality of theft, taxation and more generally rent-seeking, like for example Tullock, 228 et seq.; Cowen-Tabarrok.

${ }^{30}$ That is lost or not acquired.

${ }^{31}$ Today, for example, the recovery of legal costs is not provided for in the United States, severely limited in most other countries, and approaches the necessary only in the United Kingdom.
} 
other kind; among the latter (particularly suitable for the prevention of reiteration) stand out the custodial ones and, with less and less spread, the bodily and capital ones.

One must then ask, first, whether this increased level of prevention, always expedient exactly to prevent wrongdoings, does not itself represent, in whole or in part, an unnecessary interference in the operation of the market.

The answer, however, is negative. There is (obviously) never an interference in the market if the allocation of liability is previously accepted by a person capable of discernment and without fraud or violence (contractual liability); nor can there be one, lacking a contractual relationship between a wrongdoer and a damaged, where on the one hand the increased level of prevention is rather intended to maintain the latter's utilities, acquired originally or just through the market, and, on the other hand, the impact of that higher level on the determinations of the potential tortfeasor occurs only in terms of opportunity cost i.e. of not demonstrated (through the market), nor measurable, and then intersubjectively comparable ${ }^{32}$ preferences, and therefore is a matter of mere speculation on the subjective utility of one or another possible determination, which stresses at most the importance that, in the entire subject matter, assumes verifying the expected effectiveness of all prevention tools further than compensation.

The problem is instead different, that is that currently widely adopted law provisions concerning restoration and sanctions negate the voluntariness of the circulation of property titles and then interfere in the market, in contractual matter, overriding the will of the parties and, in non-contractual matter, giving rise to coercive transfers.

In particular, in the context of contractual relations, the provision of nullity or even an easing of "punitive" covenants alters the circulation of goods decided by the contracting parties, as it happens in many countries, including Italy, even in the case of willful default ${ }^{33}$; or also, as it happens as well, with the provision of nullity of the waiver-of-liability clauses, at least for certain cases of gross negligence or intentional non-performance ${ }^{34}$.

Nor is it necessary to spend ourselves on more or less secular justifications for such provisions: from the protection of the weaker contracting party to the safeguarding of the reciprocity of exchanges. If the market is free, the contractor is never weak; and if, without fraud or violence, a mentally capable person accepts the risk of restoration and penalties also in case of his future impossibility of performance, this is the effect of his own assessments, like many others the outcome of which he does not reckon undoing (like a wrong investment etc.) (Epstein, 2008).

In non-contractual matters, then, there is a sheer expropriation when liability is imposed on anybody who did not cause any detriment with his behavior; there is instead sheer expropriation of the damaged when, in spite of a damaging behavior, the liability of the damaging legal entity is restricted to its assets ${ }^{35}$ or the liability of the tortfeasor is excluded lacking (at least) fault.

In other words, it is true what argued Rothbard (1982b, 377 et seq., 387 et seq.), despite disagreements occurred even in the area of his Austro-libertarian $\mathrm{school}^{36}$, that is that free market entails, in the field of torts lia-

\footnotetext{
${ }^{32}$ As Mises 1912, 29, had well deduced from Menger (88 et seq.), contrasting unsuccessful attempts in the opposite direction of Boehm-Bawerk and Fisher, the subjective utility cannot be measured, but only graded always subjectively (Robbins, 121 et seq.; Einaudi, 241 et seq., where the Mengerian scale of the utility was opposed to the Benthamian one; Rothbard 1956, etc.).

${ }^{33}$ Art. 1384 c.c.: "The penalty" for willful breach "can be equitably decreased by the court, if the principal obligation has been partly carried out or if the amount of the penalty is manifestly excessive, having regard to the interest that the creditor had to the performance".

In the same way art. 1152.2 French c.c., which at least allows the judge also to increase the penalty, if this is "manifestement dérisoire..." (in the same situation, a pair of decisions of our Supreme Court suggest the nullity of the clause as contrary to the economic public policy: Cass. civ., I Sect., 02/06/1992, n. 6716; Cass. civ., I Sect., 03/12/1993, n. 12013); §§343 and 344 of the German BGB; on the other hand the reduction of the penalty in case of total contract's breach is excluded by art. 1154 of the Spanish Civil Code; the common law does not even in principle recognize validity to the penalty clauses, because true sanctions could only be imposed by the public authorities: Calamari-Perillo, 564 et seq.; among judicial rulings cf. lastly UKEAT, 08/10/2013, appl. n. 440/12, n. 5 et seq.; and it seems that our Supreme Court is "modernizing” itself on this road: Cass. civ., II Sect., 16/01/2014, n. 820, in regard to the penalties provided for by by-laws of a condominium (the Italian statutory basis of such an inference is shown by Benazzo, 163 et seq.).

${ }^{34}$ Art. 1229.1 c.c.; in France, in the absence of an ad hoc provision, it is case-law solution: Cass., comm. Sect., 29/06/2010, appl. n. 09-11841; the rule is restricted to intentional non-performance by $\$ 276.3$ of the German BGB and art. 1102 Spanish c.c.; more restrictive provisions of freedom of contract may be found in sect. 2 of English UCTA (Unfair Contract Terms Act); more permissive on the contrary the US Uniform Commercial Code (UCC) in allowing for a sale agreement, with the sect. 2-719, any not unreasonable limitation.

${ }^{35}$ Rothbard 1970, 1144 note 78, concedes that the limitation of liability for tort to the assets of a legal entity means a privilege granted to those who conduct illegal activities under this shield (see too van Dun, 3 et seq.), but notes (unsatisfactorily) that it is not certainly the prevalent indebtedness of these entities.

${ }^{36}$ Gordon, 111.
} 
bility, the necessity and sufficiency of a causal link between conduct and damage to the third party property ${ }^{37}$.

Thus, for example and always unless otherwise agreed ${ }^{38}$, it is consistent with the protection of property to hold the manufacturer liable of defective products for damages to third parties and things determined by their normal use, without bothering to investigate whether he was aware or not of the knowable defect, as it is now currently enshrined virtually everywhere ${ }^{39}$.

It is actually him who, with Epstein's words (1973, 177 et seq.), created the dangerous conditions which result in damage to others' property, given that defective products are a statistically significant outcome of the manufacturing process and the insertion on the market of a percentage of them must be put into account in spite of all pre-tests.

On the other hand, it does not matter who is the owner of the product at the time of the injury because mere ownership does not affect obviously, per se, ownership of another; nor matters who used the defective product in a way not even potentially dangerous (a problem of concurrence of causes would emerge otherwise), unless he was aware of the defect: in which case the creation of hazardous conditions, more specific than the simple manufacture and insertion on the market, would lead back the cause of the injury (and therefore liability) exclusively to his behavior ${ }^{40}$.

And for the same reason (creating more specific hazardous conditions ${ }^{41}$ or even causing a direct and intentional injury of another's property) acts of intentional sabotage of production performed by employees cannot be ascribed to the product's manufacturer, nor can be ascribed to employers in general behaviors of employees directly injurious to third parties ${ }^{42}$, by the mere fact that the offense was "occasioned" by work ${ }^{43}$.

\subsection{Higher Sanctions at Harmed Person's Sole Disposal}

Within these limits one could say that offence's sanctions higher than the mere restoration/relief of other's injured property do not interfere with, but rather preserve the market: provided however that said further sanctions do not affect, as it was feared at the end of the previous §3.1, the right of the harmed to the aforesaid restoration/relief. And, as suggested by Rothbard (1982a, 85 et seq.; in the same sense Hoppe, 113), this is possible only if not only said restoration/relief, but also these additional sanctions come anyway available to the damaged, because otherwise — as it happens to a large extent since justice too has been subtracted to privates - the harmed must to yield to, for instance, the imprisonment of the offender, the confiscation of his goods in pro of the Sovereign of the past and of today's totalitarian democracy (with the words of von Hayek, 58, 103) etc.: "Justice that

\footnotetext{
${ }^{37}$ Castronovo, 282 et seq., remembers that the mere causal link had been placed at the foundation of civil liability already from Venezian in the years 1884 to 1886, preceding by nearly a century Epstein 1973, 151 et seq. and 1974, 165 et seq.

I do not share Castronovo's negative assessment (based on the abstract—unquestionable—equivalence of all the necessary conditions and thus on the attribution of causality also to the damaged party: 336 et seq.), which finally arrives to the criterion proposed by Calabresi of imputation of liability without fault or intent to the one who is in the best suited position to conduct a costs-benefits analysis (341 et seq.): indeed and first, in identifying behaviors to be prevented and, in case, to be punished, a current (or, if you wish, approximate) notion of cause seems enough (Epstein 1973, 161 et seq., who, for the most dubious cases, develops a model of creation of hazardous conditions: 177 et seq.); then, an evaluation $a b$ externo of costs and benefits (for which see above, text and note 32) looks inconceivable and dismisses of any foundation even the whole Coasian-Posnerian system of law and economics-Block 1977, 111 et seq.; Cordato, 92, 95, 97 etc.; North, 75 et seq.- to which, besides, the here criticized opinion subtracts itself, rightly refusing an assessment of post factum et damnum datum: cf. further Colombatto 2014a, 118 et seq.); lastly, only the mere causality standard (in the sense above specified) may fulfill the needs of an absolute protection of property imposed from its conflict-minimizing function (supra, §1; it is not by chance that we read, in the report to the King on book IV of our civil code, n. 265, that it has not been admitted, even in the area of dangerous activities, "the principle of mere causality" as "unjust, antisocial and uneconomical, and such that discourages fruitful activities and initiatives").

${ }^{38}$ The pretended irrelevance of such a different agreement is criticized by Zywicki, 321 et seq., with the only acceptable remark of his Hayekian-Coasian analysis of a wrongful behavior.

${ }^{39}$ See for all the directive $85 / 374 /$ EEC.

${ }^{40}$ As rightly notes Castronovo, 438 et seq., the liability of the car's owner (and equated ones) for defects in car's manufacture, as enshrined in art. 2054.4 c.c., cannot thus be justified.

${ }^{41}$ Specific cases of creation of hazardous conditions are examined by Epstein 2010, 25 et seq. (gun illegally sold to a minor and then poorly guarded by the mother; dynamite carried by a minor with the permission of the mother).

${ }^{42}$ It is so understood by the judiciary the formula "tort... in the performance of duties to which [the employees] are assigned," used by our art 2049, and inherited from art. 1384.5 of the code Napoleon. §831.1 of BGB and art. 1903 last paragraph Spanish c.c., however, exclude liability if utmost care or, respectively, the diligence of a good pater familias on the part of the employer result, while no such limitation is found in PETL [art. 1: 101 (2) (c) and 6: 102 (1)]: cf. also Ataner, 66 et seq.

${ }^{43}$ In the case decided by the Court of Appeals of New York, 09/01/2014, Doe v. Guthrie Clinic Itd., Slip Op 138, it was rejected a claim for damages brought by a patient against healthcare entrepreneur and based on the communication, by the nurse who had participated in the admission of the patient, to her sister in law (to whom the patient was engaged) that the same patient was suffering from AIDS. And that because vicarious liability requires the tort to be committed in the employer's interest and within the scope of the employment relationship.
} 
takes possession of bankrupts' property to rob their creditors," to use the words of Voltaire (27).

One could argue that interests of third parties would remain compromised from the point of view both of generic prevention, as potential offenders should have to deal only with the harmed (whose pardon they could trust to obtain in various ways), and (above all) of the reiteration's prevention, because certain sanctions, such as typically imprisonment (but also death or amputation of limbs for thieves, robbers, etc.), make it impossible (at least temporarily) that reiteration which their pardon instead would make possible.

Nonetheless, it remains to be proved that the (un)predictable reaction of the directly injured party would not be as much deterrent as the duty to apply the sanction imposed on government officials, who are much less motivated, while an effective brake to the possibility of a waiver, in whole or partial enforcement of the sanction by the harmed would certainly be introduced by the consideration that, if an offense's reiteration was made possible by such a waiver, the injured party himself could be held liable along with the author, having contributed to cause the harmful event (by creating the danger conditions associated with the author's act).

Leaving aside most of the so-called crimes against the "public hands" and the like, according to Rothbard's vision (1982b, 409 et seq.) all the conditions for criminal law integrally collapsing into private law would thereby occur ${ }^{44,45}$. Moreover, if the contract is seen just as a means of circulation of property's titles and not of impermissible constraints of the contracting parties' will ${ }^{46}$, the contractual injury (non-performance) boils down to the torts one as in any case of infringement of another's property (that, in this case, the latter is conferred by the contract is obviously irrelevant): so it is not clear, for example, why a theft should receive additional criminal sanction and a total non-performance of a contract (maybe at remuneration already received) should not.

The just evoked Rothbardian solution, capable to favor the market's conservation, allows in any case to measure its greater or lesser distance from other current solutions. And anyone, being him a lawyer or not, knows how abysmal is this distance starting with the most serious offenses like murder: in those fewer and fewer law systems that punish it with death, the damaged person(s), regardless of the concrete circumstances and of his will, is deprived of a possible source of productive resources to be primarily allocated to compensate him; and the same goes for the other current solution of imprisoning the guilty, not matched by any duty of forced labor with devolution to the damaged party of its result net of a portion of the overall costs for supporting the sanctioning system (public or, preferably, private) and keeping the guilty alive (Rothbard 1978, 107 et seq.; 1982a, 86 et seq.).

And one could continue with the plethoric provisions, to the benefit of the public hand, of seizure of the crime price, of the instruments used to perpetrate it, of the profit derived, of the fines; in some countries, with the devolution to the State of penalties owed for non-compliance of judicial civil orders ${ }^{47}$ or even with the criminal punishment of such non-compliance ${ }^{48}$; etc.

\subsection{Punitive Damages}

The explained requirement of a disposable right of the injured party to a sanction higher than a merely compensatory one is, for instance, satisfied by the so-called punitive damages with a declared deterrence function, in their broadest meaning of pecuniary transfers to the injured person in excess of the suffered damage.

Such rewards were already provided for, as recently reminded by the United States Supreme Court, by "legal

\footnotetext{
${ }^{44}$ This of course would be a picture far more radical than the programs of private criminal restorative justice under State's protection, which gradually came into fashion (Simmons, 932 et seq.).

${ }^{45}$ Even continuing to require that the right to life (needlessly enshrined in art. 2 of the ECHR, because the property's right on your own body etc. suffices: supra, §1) is protected, against intentional attempts, by criminal sanctions in the strictest sense of the term (ECtHR, I Sect., 28/03/2000, 22492/93, v Kilic. Turkey, §62; ECtHR, I Sect., 28/03/2000, 22535/93 Mahmut Kaya v. Turkey, §85; ECtHR, Grand Chamber, 03/04/2012, 42857/05, van der Heijden v. The Netherlands, §62), the European Court of Human Rights considers that the liability for damages may lawfully exhaust the reaction to manslaughter (as well as now enshrined in Italian art. 3.1 of d.l. no. 158/2012 in case of slight medical negligence: see Cass. civ., VI Sect., 17/04/2014, n. 8940) as sufficiently dissuasive for this type of injury: cf. ECtHR, Grand Chamber, 17/01/2002, 32967/96, Calvelli a. Ciglio v. Italy, §51; ECtHR, Grand Chamber, 24/10/2002, 37703/97, Mastromatteo v. Italy, $\S 90$.

${ }^{46}$ This is common ground in the Austro-libertarian school, remaining to determine whether the inadmissibility of such constraints render inalienable the original ownership of his own body: for a minority, but persuasive negative answer Block 2003 (whose arguments seem sufficient to refute that contrary of Hoppe, 75 note 10, although not mentioned, according to which the direct control of one's body does not cease for the entire life of the person concerned).

${ }^{47}$ For example, in Germany, in accordance with $\S 888$ of the code of civil procedure and $\S 1$, paragraph $1, \mathrm{n} .3$ of the ordinance on the recovery of the costs of justice.

${ }^{48}$ The Anglo-Saxon offense of contempt of court.
} 
codes from ancient times through the Middle Ages”, which "called for multiple damages for certain especially harmful acts"; and since the eighteenth century these rewards have then been generalized by English and American judicature, with no pre-defined quantitative constraints, essentially for intentional or grossly negligent torts $^{49}$ (the mentioned rewards have also been variously regulated by statute, with regard to the different cases or classes of cases) ${ }^{50}$.

The availability of the sanctions to the injured party, leaving any decision to the agreement of the parties, reduces the trouble in determining the quantum of such damages, which is instead increased in Anglo-Saxon world by the greater uncontrollability of judgments due to the jury system ${ }^{51}$. In Italy there is no problem because some echo of this powerful tool in the prevention of wrongs occurs only in some cases (almost only in the field of intellectual property ${ }^{52}$, under the pressure of European directive n. $\left.48 / 2004\right)^{53}$, while the judiciary insists on denying the enforcement to foreign judgments which grant them, due to their contrast to the internal public policy which would admit only the patrimonial restoration of the damaged person ${ }^{54}$.

It seems however reasonable to connect also the limit of the sanctions which are higher than the restoration, to the damage inflicted on the victim: this was precisely done, with respect to the punitive damages, in the Exxon case, which refers to the absolute equivalent of the damage according to the libertarian concise rule of "two teeth for a tooth" (Rothbard 1982a, 88). In more general terms, if robbing the injuring party of his rights to the same degree in which himself has deprived the victim is added to the restoration (Rothbard 1982a, 88 et seq.; Hoppe 113 et seq.), we might even get to the death penalty (plus damages) for the murder and so on and anyway we reach a non-arbitrary basis for the quantification of the sanction.

It remains to be determined the extension of imprisonment that the injured person may esteem needed to be applied to exempt himself from liability for failure of the prevention of reiteration, according to what said in §3.4. Even on this regard, one might think to quantify in monetary terms the greater sanction, to convert it (always, of course, at the option of the injured party) in forced labor also chosen by the damaged, with the devolution to the injured party, up to the final amount, of the portion of the revenues which exceed the expenses for the offender's subsistence (Rothbard 1978, 107 et seq.; 1982a, 86 et seq.; wide discussion in Benson, 297 et seq.).

With reference to the deterrence, however, the solution may result insufficient if the harm caused is severe for the injured but the double of the equivalent, instead, negligible or however easily bearable by the offender. This is an argument often put forward against any monetary ceiling on punitive damages, which would prevent threatening (and if necessary sanctioning) adequately who has a "deep pocket". In reality, however, the parameter of the harm suffered by the victim may work here too very well, provided its evaluation as a percentage of his assets to be applied then, as a sanction, to the assets of the offender ${ }^{55}$.

It is then questionable that, according to a universal practice, the quantum of any sanction, at least additional to compensation, must necessarily decrease with the decrease of the subjective profile of the offense, which sees in scale intention, negligence and mere creation of hazardous conditions.

\footnotetext{
${ }^{49}$ For an application to a case of contractual liability with a result which, however, would have been obtained even only with a proper liquidation of loss of profit, see USSC 25/06/1993, 92-479, Txo v. Alliance, in Foro it. 1994 IV, 92 with note of Ponzanelli, G., Non c'è due senza tre: la Corte suprema Usa salva ancora i danni punitivi.

${ }^{50}$ USSC 25/06/2008, 07-219, Exxon et al. v. Baker et al., point IV A of the motivation, which yet jumps from the Code of Hammurabi (which, in the passage usually cited as §8, punished theft by the obligation to pay the owner 30 or 10 times the value of the thing stolen, according to by whom it had been committed i.e. by a patrician or a plebeian) to the statute of Gloucester by Edward I 1278 (whose chapter 5, sec. 1, provided for a penalty of 3 times the value of the thing damaged), without even mention for example the XII tables and their famous "duplione damnum "(XII fr. 3 and integration of VIII fr. 16 for the furtum nec manifestum).

${ }^{51}$ Hence the repeated, and more or less linear, attempts of the Anglo-Saxon judicial rulings to put, however, ceilings: see the aforementioned USSC on the appeal n. 07-219 of 2008 that, at point IV D, identifies the problem in the "stark unpredictability of punitive awards" and, at point IV E 3, sets a maximum ratio of 1:1 between pecuniary and punitive damages in the field of admiralty cases (whose regulation is removed from the States) absent any statutory provision (which then may not be viewed as an unfailing condition of the exemplary damages: contra Benazzo, 268 ss.).

${ }^{52}$ In other words, in defense of a regulation that is just a harmful governmental interference in the market: Boldrin-Levine. In the United States, to punish the infringement of the provisions in question and of the equally damaging antitrust ones, both within federal jurisdiction, the statutory provisions of treble damages spread (triple of suffered damages in addition to attorneys' fees that are not normally recognized): 15 USC $\$ 15$ (a); 35 USC §284.

${ }^{53}$ For a review of these provisions Riccio, 860 et seq., to which adde, for libel cases, art. 12 of the press law (no. 47/1948), which Cass. civ., III Sect., 17/03/2010, n. 6490, defines "an exceptional case of private pecuniary penalty" and therefore refuses to apply by analogy to equal unlawful act committed with the medium of television.

${ }^{54}$ Cass. civ., I Sect., 08/02/2012, n. 1781.

${ }^{55}$ The deterrence of the sanction is therefore not necessarily diminished by its parameterization to the inflicted damage, as says, for example, Becker, 198.
} 
If the parameter is the protection of property, which the market is based on (supra, §1) and regarding which any utility's intersubjective assessment, which may lead us to allow impunity for hazardous, although socially useful, activities, is impossible (supra, §3.3), the mentioned subjective profile is not conclusive, because will only makes the harm almost certain ex ante, which however ex post occurs the same way under the other assumptions.

We can certainly imagine with a certain basis that the level of sanctions required for the deterrence of malicious behavior may be higher than that sufficient for the others; but a latter's over-deterrence certainly does not affect in a negative way the deterrence of the former.

\section{Asymmetries in the Coercion to Investigate into Possible Wrongdoings}

Always remembering, with Beccaria (96 et seq.), that providing for deterrent and remedial sanctions guarantees a spontaneous and widespread compliance with the rules and, failing that, a more or less complete elimination of the harmful consequences of noncompliance, only if said sanctions, if necessary, are applied effectively and in a timely manner (supra, §3.1), it follows that reparation (and with it preservation or rough restoration of everyone's utilities) is certainly affected by an application which differs each time, which may depend on:

a) the availability of adequate means of compulsion on the parties and third parties to ascertain the truth of the facts to the base of staked claims;

b) errors, biases and abuses in the assessment of the existence and in the determination of the consequences of the offense;

c) the necessary time, widely dilated by the widespread pursuit of making sure that the related conditions occur;

d) loose rules of automatic or discretionary non-application of the sanctions so perilously determined and lack of tools to ensure their implementation.

\subsection{Criminal Matters}

In a world in which the criminal justice system, not many centuries after its inception, is still structured in terms of afflictive sanctions in prevention of, and in response to, the aggression of the "public good", it is historically consequent the universal entrusting of this sector to the activity of public officials, as well as the provision of a right to silence of the accused, overcompensated by more invasive means of ascertaining the truth (since on the one hand, by definition, the "public good" is worth more of the "private" and, on the other hand, said pubic officials are $a b$ origine without any direct knowledge of the facts, which must therefore necessarily obtain by the spontaneous or forced cooperation of others).

We can see in general, between the common law's and civil law's systems, a decreasing level of coercion of the parties to tell the truth and, more generally, to disclose their hole cards, which, in the context of the latters, is undoubtedly affected by a guarantee-oriented bias in privates' favor, well-established (and rightly so) even in the formers, in front of an investigation conducted lacking an offense to privates, but which, precisely for this reason, has no rationale in the field of pretended offenses between privates here investigated, none of whom is entitled to be guaranteed more than the other.

In other words, why the alleged murderer or thief must be guaranteed "not to be compelled to testify against himself or to confess guilt" (as stated in art. 15.3g of the UN International covenant on civil and political rights and also in other constitutions - for example in the V amendment of USA constitution ${ }^{56}$ —as well as implicitly, according to the ECtHR, also in art. 6 ECHR which requires a fair trial)? Is that in order to protect him from an "improper compulsion by the authorities, thus contributing to avoid judicial errors" ${ }^{\text {"57? }}$ ? There would be no "improper compulsion" or "risk of error" (but only potential benefits in terms of effectiveness and speed in the application of sanctions) if an additional sanction was provided for in case of having kept silent or having lied about circumstances relevant to the investigation of the offense, to be applied only in the event of a conviction. Besides this, the victim or anyway the damaged by the crime have commonly to witness, to tell the truth, to undergo the penalty for perjury regardless of the outcome of the investigation: an unequal treatment really striking, that remains concealed behind the statist bias of the "public" function of justice that, having paid the eccentric

\footnotetext{
${ }^{56}$ On the basis of the well-established English principle (Coke, XII, 26 et seq.). Art. 51.1 of Russian constitution, art. 24.2 of Spanish constitution, art. 5 LXIII of Brazilian constitution and so on have the same content.

${ }^{57}$ ECtHR, V Sect., 30/06/2008, n. 22978/05, Gäfgen v. Germany, §94.
} 
and guarantee-oriented tribute of the right granted only to the charged to remain silent or to lie, does not tolerate resistance from anyone else, even if it was the victim; intervenes discretionally, as provided by law (especially in the countries of common law), and at any rate de facto, with the more invasive investigative tools (inspections, searches, seizures of material evidence, wiretaps, etc.), generally without granting a say to the victim; spills on all members of society the relative costs and gets by us to the point of denying the refund of those paid by the accused or defendant acquitted ${ }^{58}$.

\subsection{Civil Matters}

The picture is somewhat more mixed in civil matters. We can start from the model of rule 26 of the US federal rules of civil procedure (FRCP) and of part 31 of the English rules of civil procedure (CPR), which enshrine from the outset of a civil lawsuit the duty of each party to communicate (disclose) to the others data and means of evidence in her possession relating to the respective claims and defenses, including-but only for the CPR [rule 31.6 (b) (i), (iii)] - to her counterproductive instruments; and certain exceptions to disclosure, in the American version, for cases in which action is taken against a public authority ${ }^{59}$ have to be appreciated. There is, however, no general duty of truthfulness of any statement and sanctions are only possible, at the discretion of the judge ${ }^{60}$ : this, as we saw, undermines their deterrence and does not guarantee the impartiality of the judge ${ }^{61}$.

However, this is something better than current provisions in the old continent, which generally entrust to the judge's discretion, and even only in certain cases, the imposition of a duty to tell the truth on pain of sanctions, as in case of Swiss or German law which, while requiring the parties to state completely and truly the facts of the case (\$138.1 ZPO; art. 160.1a Swiss c.p.c.) ${ }^{62}$, leave unpunished (or almost: art.191.2 Swiss c.p.c.) its infringement even in answering an, though ad hoc, examination, unless the court itself, in its discretion, decides that it has to be conducted under oath or however on pain of criminal punishment (§452.1 ZPO and §154 StGB; art. 192 and 306 Swiss c.p.c. and c.p.). Not to say that the Italian law system, like its French forebear, imposes criminal penalties on the parties only in exceptional cases in which swearing has been ordered, punishing furthermore the party's perjury with less than half of the penalty for the false witness (art. 371.1 and 372 c.p.; art. 434-17 and 434-13 of French c.p.; amplius, Tavormina 2013b).

Except for witnesses who may almost everywhere be forced, and also under threat of various sanctions, to appear before the judge or the parties' lawyers and who may also be imposed other very serious sanctions in the event of an omission, incompleteness or falsity of the statement (still Tavormina 2013b), the differences between the two models are emphasized in order to other tools available to private individuals to obtain evidence of the unlawful activity and the facts relevant to determine and acquire a compensation, which tools are, however, weaker, and sometimes by far, than those reserved to the public prosecution in criminal proceeding.

For example, even in England-Wales and the United States wiretapping communications between third parties is not allowed ${ }^{63}$ (but only, as everywhere, the record of every communication addressed, at least even, to him $^{64}$ ); there is however a wide range of investigative tools, available by coercion, either directly or indirectly (i.e. on pain of criminal penalties), including inspections of persons and things, even with forced taking of evidentiary material and so on through the classic tools of the subpoena in the United States (FRCP rules 34, 35 and 45) and the interim remedies in England-Wales (CPR part 25).

More stringent requirements and much more limited enforceability feature instead analogous tools offered by the legal systems of civil law. By way of example, in Germany the court may order to a party or to a third party

\footnotetext{
${ }^{58}$ So, for instance, Corte cost. 30/07/2003, n. 286.

${ }^{59}$ For example, FRCP, rule 26 (a) (1) (B): “(i) an action for review on an administrative record; ... (v) ... an action to quash an administrative summons or subpoena." See for example FRCP rule 37.

${ }^{60}$ See for example FRCP rule 37.

${ }^{61}$ In one case examined by Pailli, 418-419, only some of the penalties provided for have been applied and among these there was not the contempt of court.

${ }^{62}$ The need for truthful statements, however, also arises for matters of law and in particular for judicial precedents, as appropriate to affect the content of the requested ruling.

${ }^{63}$ Rothbard 1978, 133 et seq., 1982b, 82 et seq., would admit it in a libertarian law system, but only subject to the liability of those who have requested and ordered it in the event that the claim which it is aimed at would emerge unfounded: which is consistent with the vision of the offense as an objective violation of the property of others, due at least to the creation of hazardous conditions (supra, §3.3; more generally, for a liability of the public prosecutors in criminal matter that may subject them to control without the side effects of the Anglo-Saxon exclusionary rules and their old-continental imitations, Benson, 292 et seq.).

${ }^{64} 18$ USC $\S 2511(2)(c)$.
} 
to exhibit a document only if the party making the request is thereto entitled under substantive law ${ }^{65}$ or whether the counterparty has already thereto referred as evidence in the trial (§§422, 423 and 429). In Italy this is not necessary but, at least in theory (because the judiciary is sometimes more lax), it is needed not only that the court consider "necessary" the acquisition of the document (art. 210.1 c.p.c.) ${ }^{66}$, but in addition that the interested party supplies the "specific indication" of the document and "offers... evidence that the counterparty or the third party possesses it” (art. 94 disp. att. c.p.c.). After that, having overcome all these obstacles and ordered the party to exhibit the document, should he not comply therewith, in Germany at least the judge may at his discretion regard the applicant's submissions about the nature and content of the document itself as confirmed ( $\$ 425 \mathrm{ZPO}$ ), while in Italy he only may infer "arguments of proof" from this (art. 118.2 and 210.1 c.p.c.), i.e. elements thereto not sufficient alone.

Also in this area, however, as in that of punitive damages (supra, §3.5), the European Union did lay down, primarily by Directive 2004/48/EC, faithfully implemented in the member countries (see for instance in Italy art. 121bis, 127, 129 and 130 of the industrial property code), a privileged regime in favor of the holders of intellectual property rights, providing in general terms that "member States shall provide for the measures, procedures and remedies" ["effective, proportionate and dissuasive"] "necessary to ensure the enforcement of intellectual property rights" (art. 3), including the order that "evidence be produced by the counterparty," including "banking, financial or business documents that are detained by the counterparty" (art. 6), and that anyone found involved in the violation, or listed by this one as involved in, provides information thereupon (art. 8) ${ }^{67}$. And if we leave aside the fact that intellectual property is indeed averse to the market (Boldrin-Levine), the prohibition of any discrimination, based (inter alia) on "property" (inclusive obviously of its qualitative configuration), in the enjoyment of the rights and freedoms guaranteed by the ECHR and the Charter of Fundamental Rights of the European Union (art. 14 ECHR and art. 21.1 of the Charter), should impose the extension of said "effective, proportionate and dissuasive" measures to the reaction against any type of offense ${ }^{68}$ or, alternatively, lead the EU Court to invalidate the aforementioned directive by contrast to the European Treaties (art. 1.3 and 6.1 of the TEU) or (when the process of EU accession to the ECHR will have been completed) lead the European Court of Human Rights to declare the violation of the ECHR by the European Union: with an obvious superiority of the first option (market friendly) on the second one.

\section{Judicial Abuses}

\subsection{Injustice of Judicial Findings as a Common Wrong}

Including into them arbitrary or otherwise eccentric law provisions' readings as opposed to those already outlined at the time of the facts denounced as illegal (which readings, in countries such as Italy, Brazil and similar, assume quantitative dimensions of an outright interpretive anarchy), the judicial abuses are primary cause of the already mentioned uncertainty of law (supra, §2), concurrent cause of wrongs consisting in sanctioning nonexistent ones and perpetuating cause of the consequences of unduly non-sanctioned wrongs.

There would be more than enough to subdue the judges who make mistakes to the same penalties for the offenses which they are called upon to judge. Still, on the subject, probably due to earlier suggestions (ancient and less ancient) on the sacredness of the State and, gone past (or aside) those, as a consequence of other governmental branches having found themselves hostage of "the device of judicial review and interpretation" which, as said Nock $(1935,143)$, "is a process whereby anything may be made to mean anything," the judges have come to be a little everywhere, but immeasurably in Italy (i.e. just where is felt the strongest need of the opposite solution), in a regime of practical impunity.

Indeed, a regime of absolute impunity is still in force in the countries of common law ${ }^{69}$, despite their history is

\footnotetext{
${ }^{65}$ In the case decided by BGHZ, 26/06/2007, XI ZR 277/05 the appellate court had denied that this requirement occurred for documents detained by the defendant bank and attaining to the assessment of a property that the defendant was held to have fraudulently overvalued.

${ }^{66}$ That which, strictly speaking, should never occur because a decision can always be taken, even if there is no evidence of the fact that the document is intended to demonstrate. And in fact $\S 425$ ZPO requires only that the judge considers the document "relevant”, that is useful.

${ }^{67}$ With the possibility of exempting therefrom the one who was thus forced "to admit his own participation or the one of his close relatives in an infringement of an intellectual property right" (art. 8.3d): an extension to the civil sector of the nemo tenetur contra se detegere, which we already saw is inappropriate in criminal matters.

${ }^{68}$ Extension of course not be achievable through the courts, so as not to shift their acting in legislative activity: Tavormina 2013a, notes 10 and 23.

${ }^{69}$ From Star Chamber, session Easter 1607 Floyd and Barker (Coke, XII, 23 et seq.), which stated inadmissible extending to the judge a charge of conspiracy, up to USSC, 28/03/1978, 76-1750, Stump v. Sparkman, which stated the absolute immunity of a State judge who authorized, in violation of the law, the sterilization of a minor.
} 
certainly not devoid of even criminal behaviors: just remember the bribes taken and the alterations of the records made by 14 out of 16 judges charged before the parliament held at Westminster in the beginning of the year 1290 and the briberies confessed by the Lord Chancellor of England, Francis Bacon, in $1621^{70}$. Such a system spares however at least the (at least initial) distribution of damage on all citizens, leaving it entirely burdening the unlucky victims of judicial abuse.

On the contrary, in the countries of civil law the "evolution" of the rules led almost anywhere to the transition from the rule of compensatory damages to the benefit of the damaged litigant, typical of the Gaius' judex qui litem suam fecerit (Ist. 4:52), "confiscated” in various successive regimes in history (Lambertini, §3) and occasionally revived over the centuries (for example, but only for denial of justice, in title XXV of the already mentioned ordinance of Louis XIV on civil trials of $1667^{71}$ ), to the direct and exclusive responsibility of the State with its, more or less potential, later recovery against the judge. The exception is Spain, which provides for both, expressly limiting the State's liability to cases of willful misconduct or gross negligence (obviously by the judge)-art. 296 of the ley orgánica del poder judicial of 1985-and instead placing no limits to proceed directly against the judge (art. 411 et seq. LOPJ), although the judiciary has then exceedingly narrowed the scope of the provision $^{72}$.

In such a different system, the common feature is given by the (at least initial) taxation of all countrymen against damages arising from bad justice, with the consequent, inherent waste of resources should the damages even be recovered from the liable judge. There are however considerable differences as for the extent of liability and recovery against the responsible: in Germany, §839.2 of the civil code makes the judge responsible for willful misconduct or gross negligence (but suing only the State, pursuant to art. 34 of the Constitution, recourse reserved against the judge) as well as for denial of justice, only if they amount to a crime ${ }^{73}$; however, $\S 339$ of the penal code provides for the crime of "forcing the law" in favor or against one party, for which the assumption of the risk (recklessness) of a breach of law is considered sufficient ${ }^{74}$. Art. 2.1 of Italian law n. 117/1988, instead, allows the injured party suing the State in any case of willful misconduct or gross negligence of the judge, but the following paragraph 2 makes marginal such cases ${ }^{75}$; art. 13.1, which also provides that "anyone who has suffered damage as a result of an act that constitutes an offense by the judge in the exercise of his functions may claim compensation from the magistrate and the State. In this case, civil action for damages and its bringing even against the State as civil responsible are governed by the ordinary rules", is still "interpreted" (Nock 1935, 143) as preventing a direct action against the judge ${ }^{76}$ and, on the other hand, has very limited scope for the absence, in our system, of a penal statutory provision as extensive as the German one; last but not least, the State (mandatory: art. 7.1) recourse against the judge "cannot exceed a sum equal to one-third of annuity's salary”, except in case of intentional misconduct (art. 8.3) ${ }^{77}$.

\subsection{State's Liability for Judicial Wrongs}

The framework described in the previous §5.1, so far as it is relevant here, did undergo some variation of a cer-

${ }^{71}$ To which can be added, again as an example, the provision of tit. XXIII $\S 5$ of the AGO of Frederick the Great in 1781, above mentioned too, according to which, in the event of invalidity of the proceedings in first instance, the judge of this was required to reimburse both parties the costs there incurred.

${ }^{72}$ Supported by a couple of references to inexcusable ignorance left in the LEC (art. 266, $1^{\circ}$ and 403.2), as well as by a part of the academic community, Spanish decisions persist in affirming that the limit previously in force of negligence or inexcusable ignorance is operative, with a result quantified by Oliva Blázquez, 10 et seq., so far only in three awards for damages in more than one century; but there's at least a fourth: STS, I Sala, Sec. $1^{\text {a }}$, 20/12/2006, n. 1161, RJ 2007/383.

${ }^{73}$ The provision applies only to judgments. In the interim orders, instead, courts hold that the liability (always of the State) may be established in any case of willful misconduct or gross negligence: BGHZ, 03/07/2003, III ZR 326/02, point 2 of motivation.

${ }^{74}$ BGHSt, 22/01/2014, 2 StR 479/13, n. 2 of reasons in law.

In Spain, instead, the gross negligence or inexcusable ignorance that caused an unjust decision is punished with disqualification from public offices from two to six years (art. 447 c.p.).

${ }^{75}$ “In the exercise of judicial functions neither the activity of interpretation of law nor that of facts and evidence's assessment may give rise to liability”: a grotesque formula to sanction the irresponsibility of the judges, observes Oliva Blázquez, 47.

${ }^{76}$ Cass. civ., III Sect., 03/01/2014, n. 41.

${ }^{77}$ The CSM (High Council of Judiciary), in its opinion of October 292014 on the government bill A.S. 1626 on the reform of the so-called civil liability of the Judiciary (which reforms almost nothing), commenting on the proposed abolition of the filter to the litigation at issue (for that matter maintained admissible only against the State), holds as unacceptable that "the institute of civil liability [is] used to put pressure on judges in order to increase the diligence of the individual and the quality of the jurisdiction"; and argues that it should instead be insisted "on ordinary remedies" (7.3 years of average duration), "on the compensatory tools" (we all have to tax ourselves to pay for the mistakes of the judges), "on institutional measures" (whose fruits we are appreciating since 60 years).
} 
tain importance in the European context due to the enforcement of the ECHR and the EU Treaties.

Obviously the influenced matter is limited to that pertaining to the above-mentioned international conventions which, grossly speaking, concerns essentially procedural guarantees provided for by the ECHR (European Court restates constantly that it is not its task, to no effect, surveying the justice of national denounced decisions) and the Union's own issues (freedom of movement, competition, consumer protection under pretext of leveling the field, etc.) as regards the Treaties.

In both the above mentioned areas, European Court and the Court of Justice affirmed the State's liability for bad justice against its residents, which was certainly an innovation for the United Kingdom. Said liability, on the other hand, has not been extended directly to the judge, thereby leaving member States free to charge him with it or burdening the subjects therewith, but always as warrantor and hence with the related waste.

Within these limits, however, both Courts have rightly refused that unorthodox decisions can be justified with a supposed freedom of law's interpretation, at least in front of a manifest violation not only of the text, but also of the interpretation given to it by themselves Courts: thus reducing at least a bit the ambit within which each word of the law can signify anything.

\subsection{Personal Liability for Judicial Wrongs}

The (ab)used argument to exclude the direct personal liability of the judge towards the victim of any kind of violation of his duties is that it is a necessary evil for preserving his independence ${ }^{78}$; but the argument does not hold water because it is obvious that subjecting the judge to the judgment of other his colleagues as much independent cannot, by itself, undermine his independence on pain of contradiction (if independence characterizes the judgment, it works both when he is judging and when is judged). And if the "fear" of being misjudged can cause him "judging otherwise than him dictate science and conscience" ${ }^{\text {"79 }}$, it is consistent requiring by him the same faith he requires by his adjudged.

Nor can we say, with some frantic supporters of this Richterspruchprivileg, that this would be justified by the peculiarities of the task of the judge, who necessarily has to give wrong (if only partially) at least to one of the litigants and therefore is exposed with certainty, at the very least, to the complaints of one party: in fact, such a position is common to the members of tender committees, competition committees (formal and informal), arbitration panels ${ }^{80}$ etc., to none of which such a privilege is granted.

Besides, the reported arguments support better an absolute judicial impunity, such as that which exists formally in the countries of common law and substantially in Italy, rather than a necessary interposition of the State between the claim of the injured and the judge liability's pronouncement.

And indeed, requiring that the judicial abuse is first stated in a case between the victim and the State, to impose or authorize this then to seek recourse in another lawsuit against the author, entails:

-identity of the alleged risks for the independence of the judge, who knows to be nevertheless exposed to a recourse's claim by the State;

-passing on the countrymen the costs of one lawsuit more;

-these ones advancing the costs of any award;

-a sort of taxation for such compensation at the discretion of the administrative authority, if the recourse's claim against the author of the abuse is optional;

-greater uncertainty in applying the sanction and thus a decreased suitability to generic and reiteration's prevention, due to the possible divergence of the outcome of the recourse's lawsuit with respect to the prior decision to establish liability (which would furthermore result in the striking emergence of a further judicial error and the final passing on the fellow countrymen of the damage caused by the author of the abuse, contrary to the law provision).

\section{Delays in Applying the Sanctions}

\subsection{In General}

It comes, as always, at root, to the failures induced by State's monopoly of the jurisdiction and, in criminal field,

${ }^{78}$ BGHZ, 03/07/2003, cited above; Italian const. court 19/01/1989, n. 18, point 9 of the reasons in law.

${ }^{79}$ Italian Const. Court, n. 18/1989, cit. above, loc. cit.

${ }^{80}$ In the end, as acutely notes Benson, 294, judges, like all other State officials (16 et seq.), are just privates, paid for with money stolen from other individuals to impose the point of view of said officials; the latter thereto entitled-I might add-from that infallibility in the choice of their leaders, in the context of a method called democratic, which is acknowledged to a quorum of individuals to whom is subtracted less money than to others. 
even of judicial action. Entrusting this latter (or even just sentencing and enforcing judgments) to a monopolistic operator is the most reliable way to place its costs and efficiency out of control. Optimal solution would be therefore to eliminate the State and to leave the task to a voluntary regulation between parties; failing such solution, at least free competition should be granted and the settlement with private arbitrators should be allowed in any case ${ }^{81}$.

\subsection{Faulty Rules}

Besides, the authoritative public regulation presents defects of variable severity already in the design of the instrument for the application of the sanctions. If the latter must be fast, a reduction of the time for establishing the offense would be needed; and then it should:

a) be allowed, on the mere allegation of non-performance by the person entitled, the direct intervention of the enforcement officer for the execution of a civil obligation (and accessories fixed by law or contract) that results from a document with adequate guarantees of authenticity, subject to the possibility for the compelled person to submit to a judge any of his reasons, upon, where appropriate, invalidation or suspension of the execution acts already carried out depending only on the greater or lesser foundation of his defenses;

b) be provided for the rest, regardless of any requirement of urgency, a preliminary judicial examination of the advanced claim, opening the way, without further delay, to the enforcement of the ensuing order (at least for any penalty not exceeding the deprivation of liberty) where no serious contestation emerge (on the model of the French civil référé deprived of the urgency: art. 808 et seq. French c.p.c.), without prejudice of any subsequent deepening on motion of the interested party;

c) all at the risk of those who claim the performance and/or the penalty, whose undue (total or partial) enforcement should represent in itself an offense, even if provisionally allowed by the judge.

Now, the solution sub a) is widely adopted, but with significant impairments. For example, in Italy you may start enforcement proceedings to get what is due under public act (art. 474, n. 3 c.p.c.) or even just a private contract authenticated by a public official or even bills of exchange, checks etc. with unauthenticated subscription, but then only if the obligation due is a sum of money (art. 474, n. 2 c.p.c.). It does not suffice, however, even the public act if all the conditions of the obligation do not emerge from the same act, without reference to other source ${ }^{82}$ : and it is not clear why ${ }^{83}$. You cannot get, in case of apparent merits of the opposition, the annulment of the execution acts which have already been carried out ${ }^{84}$, while the mere stay of execution is entrusted to the existence of not better specified "serious reasons", which (looking at things on the other side) could therefore identify themselves even in the burdensomeness of performance required, legitimizing the protraction of a maybe even blatantly illegal behavior.

Even in Germany the court's powers in enforcement challenging's proceedings are largely discretionary, even if explicitly extended to the annulment of measures already taken (as well as in France: art. L121-2 c.p.c. on enforcement and L213-6 code of judicial organization) and influenced by the challenge's chances of success (§§769 and $795 \mathrm{ZPO}$ ).

The solution sub b) is instead virtually unknown everywhere, due to the bias, by now encrusted often in the wording and always in the interpretation of international conventions and constitutions, according to which no sanction, much less criminal, may be applied unless by virtue of a full judicial inquiry, and not only of a high probability, that all the related requirements are met: a protective position, certainly, but of what? Of a factual present situation, silent by itself on the events which produced it and certainly not deserving protection against an high probability that it arose illegally.

Of course the counterbalance of the unconditional responsibility of anyone (applicant, adjudicator, etc.) who

\footnotetext{
${ }^{81}$ Also for the enforcement proceedings, as I think to have already shown being even today legally possible, albeit within narrow limits, for the civil sector in Italy: Tavormina 2006, 1621 et seq.

${ }^{82}$ Cass. civ., III Sect., 18/01/1983, n. 477, in Giust. civ., 1983, I, 1493; Trib. Roma, 28/07/1998, in Dir. fall. 1999, II, 150. Now, following Cass. civ., Un. Sect., 02/07/2012, nn. 11066 and 11067, which have stated that an enforceable judgment may be integrated with the findings of the pleadings, the solution may change.

${ }^{83}$ The "decades of discussion on self-sufficiency of the enforcement title, on the clear cut between cognition and execution, on the merely instrumental task of enforcement officers," of which speaks Della Pietra, 1, criticizing the most recent decisions of the Supreme Court cited in preceding footnote, have certainly helped to understand what we are talking about, but cannot justify the crystallization of inadequate solutions.

${ }^{84}$ Here, too, now Cass. civ., III Sect., 08/02/2013, n. 3074, at point 3.6.1 of motivation, has opened new perspectives by giving the judge the discretion to annul, in whole or in part, the enforcement's acts already carried out when he deems to stay the enforceability of a judgment.
} 
erred in moving for or allowing the sanction's enforcement is needed, where it is subsequently verified that there was no offense.

And instead, the imposed model is that of a prior full verification with all the necessary time; of an anticipation limited to civil sector and exceptional cases, with all the associated margin of discretion of the judges; of more or less marked impunity not only of the latters, but also of the applicant and of other possible co-authors for penalties abusively imposed (as well as denied) ${ }^{85}$. The damage to be assessed as consequence of the lapse of time increases thus dramatically; various harmed are, more or less randomly, discriminated; the effects of injuries temporarily disregarded are perpetuated (and in addition new ones are made legal).

\subsection{Lengthy Proceedings}

Obviously, the faults induced by the monopoly of jurisdiction (\$6.1) added to a model of the type described above (\$6.2) vary quantitatively in function of the total request to the officials who administer justice (which in turn depends on the rate of legality of the social body and the ease of access to the courts), in function of the resources that the government decides to dedicate thereto and in function of the personal commitment of individual employees, lacking any lawful incentive other than modest career prospects, for the proper and efficient performance of their duties i.e. in function of their duty's sense or ethic rate.

In the most advanced countries the time needed to obtain an ordinary enforceable decision are relatively low (still never lower than a few years), with variations due to the choice between the attribution of immediate enforceability to a first decision, or to that which intervenes at the end of an eventual appeal. Thus, in countries of common law a certain trend towards limiting ways and grounds of an appeal makes all decisions enforceable, except the automatic stay of death penalty in the USA [rule 38(a) of the FRCrP)] and the possibility for the appellant to obtain release on bail or a stay of execution [English rules 68.8 CrPR and 52.7 CPR; US rules 38(b) FRCrP and 8 FRAP]. In contrast, in countries of civil law, the execution of criminal sentences is always automatically stayed as a result of the appeal (§449 German StPO; art. 708.1 French c.p.p.; art. 141 and 988.1 Spanish LECr; art. 650.1 Italian c.p.p.), while for civil judgments, some jurisdictions do provide for a stay, without prejudice to the possibility to obtain from the court an order for immediate enforcement ( $\$ 704$ German ZPO and art. 539 French c.p.c.), and others provide for an immediate enforcement, allowing the court to order a stay (art. 527.3 Spanish LEC and 282-283 Italian c.p.c.).

All of these behavioral, technical, financial and regulatory constraints sufficiently explain certain trends emerging from official statistics, although the latters' credibility should be thoroughly verified, both because the method of data collection is generally not exposed in all its details, and because certain results collide with the common experience.

In this regard, it is enough limiting oneself to examine the 2010 data made available by the CEPEJ, i.e. the Commission established by the Council of Europe for evaluating the effectiveness of the European judicial system (thus excluding the United States), to verify that the most reduced business volumes are, in order, those of England-Wales and Germany (4/5 times more than the former), substantially equivalent for the criminal and civil sector; France follows, more or less at par with Germany for the criminal field, but with a surplus of the civil one on the criminal of about 70\%; and finally, more or less at par between them, Spain and Italy with a surplus on France of about 75\% in the criminal and of about 45\% in civil area (CEPEJ, 200 and 175: 2010 data for $100,000$ residents, new proceedings and only for the first instance $)^{86}$.

The reported data certainly reflect the decreasing rate of legality found in the different geographical areas, but also the growing activism of the PP which the prosecution is reserved to and, in the civil sector, the cost of access to justice, decreasing for the individual (who then exploits it), and instead passed in part on the community, through general taxation, and for the rest assumed by those who most need to speed up and instead see a continuous extension of the proceedings' time. In fact, with disbursements in favor of the State which the private is called to for accessing to civil justice, England-Wales covers $33.4 \%$ of the costs for the judging activity

\footnotetext{
${ }^{85}$ For example, in Italy there is absolute impunity, of the judges (supra, §5) as well as the PP and also of the complainant in criminal matters (the latter's behavior can just amount to a false charge, which however, requires the knowledge of the innocence of the accused: art. 368 c.p.); and in civil matters unlawful enforcement proceedings may give rise to liability only if there is also negligence (art. 96.2 c.p.c.). In France, the enforcement of a civil judgment, then overwhelmed by the Supreme Court, can give rise only to refunds and can never result in a tort (art. L111-11 c.p.c. on enforcement).

${ }^{86}$ For civil lawsuits data are more or less confirmed by UE Commission, 5 which refers to civil litigation pending in 2012 (impossible to collect for the UK), but with significant inconsistencies which cannot be deepened here.
} 
(CEPEJ, 77); Germany covers an unspecified, but more than 50\%, percentage thereof (CEPEJ 77 in relation to 30); France nothing (CEPEJ, 79); Italy 10.7\% (CEPEJ, 77) and Spain still less (CEPEJ, 77 in relation to $30^{87}$ ).

The results in terms of the length of the proceedings are those that can be expected: the data collected by the CEPEJ are particularly poor with regard to criminal trials; for example, we learn that the duration of a procedure of first instance for burglary is 174 days in England-Wales ${ }^{88}$, 278 days in France and 826 in Spain. From other sources we learn that the average length of criminal proceedings before a court of first instance was 6.6 months (200 days) in Germany in $2012^{89}$ and 358 days in Italy in 2012-2013 $3^{90}$.

For civil cases before the courts of first instance (which should also incorporate the judges of peace and similar, with very simple affairs), the times for the year 2010, reported by CEPEJ, have been 184 days for Germany, 279 for France, 289 for Spain and 493 for Italy (CEPEJ, 184) ${ }^{91}$, while in England-Wales comes to 56 weeks (392 days), although only for disputes with a value exceeding $£ 10,000$ (excluding thus the lower courts) ${ }^{92}$. The Italian (as well as Spanish) data raise some doubts, not only because from the findings of the Permanent Observatory on the exercise of jurisdiction of the CNF emerges a life of trials before civilian courts of 3.1 years in $2012^{93}$, but also because it suffices to consult, on any of the available websites, judgments filed in the courts of Milan and Rome to verify, by comparing the initial year of the proceedings, which can be deduced from the number of general role therein reported, with the year of filing of the decision, that the duration is practically never less than 2 years and often reaches $4 / 5$ years; and because, regarding sentences passed by the Court of human rights for slowness of judicial proceedings, Italy beats Spain 50 (41 civil and 9 penal) — 0 , beats France 50-2, beats Germany 50-18 (2010: CEPEJ, 172).

It must only be added that the (almost) free access to civil justice, which characterizes France, Italy and Spain, is not univocally related to an increased workload which might justify the longer duration of proceedings, as the French case shows. Thus, there are certainly concurring reasons of organization and commitment of the players. In addition, the combination of (relative) speed of the proceedings in first instance and immediate enforceability of the decisions that conclude them certainly creates, in England-Wales, a more favorable environment for the holders of the infringed rights ${ }^{94}$; and the selection between these made in France and Germany, due to the non-automaticity of the enforcement of the decisions of first instance, allows to take greater account of the doubts that certain decisions raise and the related delays are to some extent offset from a significant reduction in duration of the second instance ( 0.99 years in France and 0.56 years in Germany ${ }^{95}$ vs. 3.4 years in Italy: CEPEJ, 169 and table 16).

\section{Nullification of the Sanctions}

As it is intuitive and as also Beccaria and his grandson Alessandro Manzoni (the latter speaking of the "gride" of the Spanish Government in Milan '600), among others, remembered, the level of sanctions' prevention (generic and of reiteration) is proportional both to their entity and to the probability of their practical application so as to enable to contain the first while the second is increasing (much more problematic the reverse operation, which leads directly to the practical ineffectiveness of the already mentioned Manzonian gride): these considerations underlie the advocated exclusion of punitive damages for easy verifiable violations (Polinsky-Shavell, 878 et seq.).

Obvious consequence is that, if the law provides that the even identified offender has the right to (or even a legitimate expectation to) avoid, stop or anyhow reduce the penalty according to its own (more or less flawless) future behavior (parole release, sentence reduced by good behavior, limitation of liability to existing assets through discharge from debts in bankruptcy or quasi-bankruptcy proceedings, etc.), the prevention's function

\footnotetext{
${ }^{87}$ As for Spain, the calculation was made by dividing the absolute amount of p. 77 to the total of the amounts of p. 30 , which however also includes the expenses incurred for the office of PP.

${ }^{88}$ It is faster to keep oneself up to date by consulting http://open.justice.gov.uk/courts/criminal-cases.

${ }^{89}$ Bundesamt für Justiz Referat III 3 Stand: 12. November 2013,

www.bundesjustizamt.de/DE/Themen/Buergerdienste/Justizstatistik/Geschaeftsbelastungen/Uebersicht_node.html. It should however be borne in mind that it is included the Zwischenverfahren, which corresponds to our phase of the case before the GUP.

${ }^{90}$ Report on the administration of justice in 2013, 103, http://www.cortedicassazione.it/Documenti/Relazione_anno_giudiziario_2013.pdf

${ }^{91} \mathrm{OECD}, 2013$, 2, shows instead-for the same year-the figure of 564 days.

${ }^{92}$ http://open.justice.gov.uk/courts/civil-cases/

${ }^{93}$ http://www.consiglionazionaleforense.it/site/home/naviga-per-temi/in-evidenza/articolo8457.html.

${ }^{94}$ This is reflected by inflows of foreign direct investment: OECD, 2014, Table 1.

${ }^{95}$ OECD, 2013, 12.
} 
goes proportionally lost, with that of the restauration of the offense's consequences. And this should be taken into account when assessing the impact of contrasting wrongs on the extent of the market (Tavormina 2014).

As I mentioned in the previous §3.4, it can be assumed that the loss of function in question is less if the avoidance in whole or in part of the penalty is not matter of a right or legitimate expectation of the offense's author, but of judicial arbitrariness and even more of the consent of the injured party: and it is not needed lingering to detect which one of the two ways is the most dangerous and which, instead, the preferable one.

Even outside of hypotheses which have been mentioned, then, the concrete implementation of the sanction may be prevented and, correspondingly, the function of prevention can be downgraded, not only by the structural impossibility to force certain performances (those so-called not fungible), but also by a pre-fabricated or actual lack of assets on the part of the punished, who then does not pay the amount due as main penalty or in lieu of the incoercible performance. And in this case, while in the field of criminal law is generally provided for the transformation of the pecuniary penalty into detention, with mitigations of various extent, in the civil sector the various legal systems resort to devices of different effectiveness, to punish the non-performance and also to identify distrainable assets; failing which the penalty is left unenforced, reducing its prevention's function to the threat of a future enforcement dependent on a hypothetical change in the conditions to which the sanctioned could be pushed even only by his needs of surviving.

Although the near disappearance of arrest for debt is considered a great achievement of civilization, we have already seen in the previous $\$ 3.4$ that there is certainly doubt on the rationality of the different treatment accorded to criminal and civil penalties.

In any case, the standards of the related devices should be aligned in the enforcement of civil penalties. So, for the non-performance of a not pecuniary obligation, both in the United States [rule 70(e) FRCP] and in England-Wales [rule 70.2A(4)(b) CPR] it is provided for a criminal penalty for contempt of court, at discretion of the court; in Germany mandatory fines up to 250,000 euro are applied, and lacking payment, detention up to six months (§888 ZPO); in France, Spain and Italy compulsory pecuniary penalties (art. L131-1 et seq. French c.p.c. on enforcement; art. 709 et seq. Spanish LEC; art. 614bis Italian c.p.c.).

For the execution of pecuniary obligations it matters a lot the possibility for the enforcement officer to acquire all possible information about the existence of assets available to the enforced party, either from the latter under threat of further sanctions, or from third parties. And if, with regard to the first path, there is now a certain alignment in the imposition of a statement whose omission or falsehood is criminally punished [rule 69(a)(2) Americans FRCP; Part 71 English CPR; §802c et seq. German ZPO; art. 589.2 Spanish LEC and 556 c.p.; art. 492.4 Italian c.p.c. and 388.6 c.p.], the second is also generously open in various systems [see the same rule 69(a)(2) US FRCP; rules 25.1(1)(j), 25.1(3), 25.2(1)(b) English CPR; art. 591 Spanish LEC], at least in respect of public bodies and banks (art. L152-1 et seq. French c.p.c. on enforcement), while a few provide for more limited access (\$802l German ZPO: bodies of compulsory insurance, banking data at the tax authority and vehicle register; this provision has been now translated into the brand new art. 492bis Italian c.p.c.).

\section{Summing-Up}

For the reasons mentioned sub §1, the market must be defended (also) against the countrymen’s offenses minimizing the costs involved.

Obvious precondition is an as precise as possible predetermination of the offenses, so that who wishes to avoid committing an offense is able to plan his action and trust (in the proper limits of his devised defense) that third parties will not commit one. So, if the rate of interpretive anarchy is particularly high, such as in Italy, it should at least be required that the judicial decision on facts, by definition already occurred, reflects the interpretation of the higher-level judicial authority and, in second place, the hitherto prevailing interpretation, which may be changed only for the future (\$2).

The more effective regulatory device in preventing wrongs seems the threat of sanctions in excess of the redress, and which could, if necessary, prevent their recurrence, entrusting the decision on their application to the injured party, who should at the same time be the only entitled to reap the benefit, without distinctions between crimes and civil wrongs (§3).

The credibility of the threat, as well as any actual restauration of the harm and prevention of reiteration, requires accuracy and speed in the application of sanctions and therefore:

-the parties should have the duty to tell the truth; the penalties for the offense actually committed should be 
increased in the event of breach of said duty and the instruments for finding the facts should be strengthened, although the applicant should be held liable in case he results eventually wrong (§4);

-the judges' mistakes should be sanctioned as well, since the judges concur with the applicant in commit-ting or in perpetuating the consequences thereof (depending on whether they erroneously held or denied the existence of the offense) (§5);

-the state jurisdiction should be put in competition with the private (arbitration) and in any case should be drawn so as to favor a rapid application of sanctions against an incontrovertible finding of the facts (§6);

-any form of penalties' remission should be subject to the consent of the injured party and it should be provided for forced labor lacking any other offender's asset as well as free access for the enforcement officer at every information's source on the resources of the sanctioned (§7).

\section{References}

Arruda Alvim Wambier, T. (2013). Principio dell'isonomia e giurisprudenza in Brasile, un paese di civil law. http://www.aispc.it/documenti/Materiali/Wambier\%20lezione\%20sul\%20precedente.pdf

Ataner, A. (2006). How Strict Is Vicarious Liability? Reassessing the Enterprise Risk Theory. University of Toronto Faculty of Law Review, 64, 63-103.

Bastiat, F. (1864 [1850]). Harmonies économiques, Oeuvres completes (5th ed.). Paris: Guillaumin et Cie.

Beccaria, C. (1809 [1764]). Dei delitti e delle pene. Livorno: Gaetano Martini.

Becker, G. S. (1968). Crime and Punishment: An Economic Approach. Journal of Political Economy, 76, 169-217. http://dx.doi.org/10.1086/259394

Benazzo, P. (2005). Le "pene civili” nel diritto privato d'impresa. Milano: Giuffrè.

Benson, B. L. (1998). To Serve and Protect-Privatization and Community in Criminal Justice. New York \& London: New York University Press.

Block, W. (1977). Coase and Demsetz on Private Property Rights. Journal of Libertarian Studies, 1, 111-115.

Block, W. (2003). Toward a Libertarian Theory of Inalienability: A Critique of Rothbard, Barnett, Smith, Kinsella, Gordon, and Epstein. Journal of Libertarian Studies, 17, 39-85.

Boldrin, M., \& Levine, D. K. (2008). Against Intellectual Monopoly. New York: Cambridge University Press.

Calamari, J. D., \& Perillo, J. M. (1977). The Law of Contracts (2nd ed.). St. Paul, MN: West Publishing Co.

Campbell, J. (1851 [1845]). Lives of the Lords Chancellors and Keepers of the Great Seal of England from the Earliest Times till the Reign of George IV (2nd ed.). Philadelphia, PA: Blanchard and Lea.

Castronovo, C. (2006). La nuova responsabilità civile (3rd ed.). Milano: Giuffrè.

CEPEJ (2012). Evaluation Report on European Judicial Systems. http://www.coe.int/t/dghl/cooperation/cepej/evaluation/2012/Rapport_en.pdf

Coke, E. (1572-1617 [1777]). The Reports of Sir Edward Coke, Knt. (5th ed.). VII (Part XII-XIII), London: J. Rivington and Sons, Etc.

Colombatto, E. (2011). Markets, Morals and Policy-Making. London \& New York: Routledge.

Colombatto, E. (2014a). A Free-Market View on Accidents and Torts. Duke Law Journal, 77, 117-133.

Colombatto, E. (2014b). Essentials of Economics. Unpublished.

Condillac, É. B. (1776). Le commerce et le gouvernement, considérés relativement l'un à l'autre. Amsterdam: Jombert \& Cellot.

Cordato, R. (2007 [1992]). Efficiency and Externalities in an Open-Ended Universe: A Modern Austrian Perspective. Auburn, AL: Ludwig von Mises Institute.

Cowen, T., \& Tabarrok, A. (1999). The Opportunity Costs of Rent Seeking. Journal of Public Finance and Public Choice, 17, 121-127.

de Molinari, G. (1849). De la production de la sécurité. Journal des Economistes, 21, 277-290.

Della Pietra, G. (2014). L'outsourcing del titolo esecutivo (e dei provvedimenti giudiziali in genere): Si parva licet componere magnis. 1-6. www.judicium.it

Eabrasu, M. (2009). A Reply to the Current Critiques Formulated against Hoppe’s Argumentation Ethics. Libertarian Papers, 1, 1-29.

Einaudi, L. (1940). Miti e paradossi della giustizia tributaria (2nd ed.). Torino: Giulio Einaudi. 
Epstein, R. A. (1973). A Theory of Strict Liability. The Journal of Legal Studies, 2, 151-204. http://dx.doi.org/10.1086/467495

Epstein, R. A. (1974). Defenses and Subsequent Pleas in a System of Strict Liability. The Journal of Legal Studies, 3, 165215. http://dx.doi.org/10.1086/467512

Epstein, R. A. (2008). Liability. In R. Hamowy (Ed.), The Encyclopedia of Libertarianism (pp. 293-294). Los Angeles, London, New York \& Singapore: SAGE Publications.

Epstein, R. A. (2010). Toward a General Theory of Tort Law: Strict Liability in Context. Journal of Tort Law, 3, 1-47.

EU Commission (2014). The 2014 EU Justice Scoreboard. http://europa.eu/rapid/press-release_MEMO-14-194_en.htm

Fornaciari, M. (2012). Il risarcimento del danno da lesione del possesso. Rivista Trimestrale di Diritto e Procedura Civile, 66, 89-116.

Galles, G. (2014). Markets Are about Much More than Material Goods. Mises Daily, 1.4.2014. www.Mises.org

Gordon, D. (1993). Toward a Deconstruction of Utility and Welfare Economics. The Review of Austrian economics, 2, 99112. http://dx.doi.org/10.1007/BF00842706

Hoppe, H. H. (1987). Eigentum, Anarchy und Staat. Opladen: Westdeutscher Verlag. http://dx.doi.org/10.1007/978-3-322-88644-6

Jevons, W. S. (1871). The Theory of Political Economy. London \& New York: Macmillan and Co.

Lambertini, R. (2010). Giustiniano e il iudex qui litem suam fecerit. http://www.studitardoantichi.org/einfo2/file/1290518727-Lambertini\%202.pdf

McBride, W. (2012). What Is the Evidence on Taxes and Growth? Tax Foundation Special Report No. 207, 18.12.2012. www.taxfoundation.org

Menger, C. (1871). Grundsätze der Volkswirtschaftslehre. Wien: Wilhelm Braumüller.

Nock, A. J. (1943). Memoirs of a Superfluous Man. New York \& London: Harper \& Bros.

Nock, A. J. (1948). A Journal of Forgotten Days, May 1934-October 1935. Hinsdale, IL: H. Regnery Co.

Nock, A. J. (1950 [1935]). Our Enemy, the State. Caldwell, ID: Caxton Printers Ltd.

North, G. (2002). Undermining Property Rights: Coase and Becker. Journal of Libertarian Studies, 16, 75-101.

OECD (2013). Civil Justice: How to Promote Its Efficiency? OECD Economics Department Policy Notes, 18, 1-12.

OECD (2014). FDI in Figures. http://www.oecd.org/daf/inv/FDI-in-Figures-April-2014.pdf

Oliva Blázquez, ET SEQ (2010). Responsabilidad civil de los jueces y magistrados por ignorancia inexcusable. Indret, 4, 157.

Pailli, G. (2012). Produzione di documenti elettronici (e-discovery) negli Stati Uniti e nell’Unione europea. Rivista di Dirritto, I, 409-430.

Perkerson, E. (2010). The Antiregulation Case. Mises Daily, 4.8.2010. www.Mises.org

Polinsky, A. M., \& Shavell, S. (1998). Punitive Damages: An Economic Analysis. Harvard Law Review, 111, 869-962. http://dx.doi.org/10.2307/1342009

Riccio, A. (2009). I danni punitivi non sono, dunque, in contrasto con l'ordine pubblico interno. Contratto e Impresa, 854881.

Robbins, L. (1932). An Essay on the Nature and Significance of Economic Science. London: Macmillan and Co.

Rothbard, M. N. (1956). Toward a Reconstruction of Utility and Welfare Economics. In M. Sennholz, Ed., On Freedom and Free Enterprise-Essays in Honor of Ludwig von Mises. Princeton, NJ: D. van Nostrand Company Inc.

Rothbard, M. N. (1998 [1982a]). The Ethics of Liberty. New York \& London: New York University Press.

Rothbard, M. N. (2006 [1978]). For a New Liberty-The Libertarian Manifesto (2nd ed.). Auburn, AL: Ludwig von Mises Institute.

Rothbard, M. N. (2006 [1995]). An Austrian Perspective on the History of Economic Thought (2 vols.). Auburn, AL: Ludwig von Mises Institute.

Rothbard, M. N. (2009). Man, Economy and State with Power and Market. Auburn, AL: Ludwig von Mises Institute.

Rothbard, M. N. (2011 [1982b]). Law, Property Rights, and Air Pollution. Economic Controversies. Auburn, AL: Ludwig von Mises Institute.

Simmons, R. (2007). Private Criminal Justice. Wake Forest Law Review, 42, 911-990.

Smith, G. H. (1979). Justice Entrepreneurship in a Free Market. Journal of Libertarian Studies, 3, 405-426.

Tandy, F. D. (1896). Voluntary Socialism—A Sketch. Denver, CO: Francis D. Tandy Pub. 
Tavormina, V. (2006). Sul contratto di accertamento e sulla tutela, anche cautelare ed esecutiva, a mezzo di arbitri irrituali. Corriere Giuridico, 1614-1623.

Tavormina, V. (2011). Il diritto di libertà da indebita coazione: Una parte integrante dell'oggetto di ogni processo. Rivista di Dirritto Civile, I, 375-414.

Tavormina, V. (2013 b). Tutta la verità e nient’altro che la verità: Parti e testimoni nel processo civile. Giusto Processo Civile, 1153-1157.

Tavormina, V. (2013a). Diritto e processo rivisitati. Jus, 47-107.

Tavormina, V. (2014). Insolvency Regulations and Economic Recession: An Austro-Libertarian Point of View. Beijing Law Review, 5, 149-154. http://dx.doi.org/10.4236/blr.2014.52014

Thrush, A., \& Ferris, J. P. (Eds.) (2010). Bacon, Sir Francis. In A. Thrush, \& J. P. Ferris (Eds.), The History of Parliament: The House of Commons (pp. 1604-1629). London: Cambridge University Press. http://www.historyofparliamentonline.org/volume/1604-1629/member/bacon-sir-francis-1561-1626

Tullock, G. (1967). The Welfare Costs of Tariffs, Monopolies and Theft. Western Economic Journal, 5, 224-232.

Turgot, A. R. J. [1919 (1769)]. Valeurs et monnaies, Oeuvres de Turgot et documents le concernant avec biographie et notes par Gustav Schelle, III. Paris: Félix Alcan, 79-98.

UE Commission (2014) The 2014 EU Justice Scoreboard. http://europa.eu/rapid/press-release_MEMO-14-194_en.htm

van Dun, F. (2008). A Note on the Austro-Libertarianism and the Limited-Liability Corporation. 1-9.

http://users.ugent.be/ frvandun/Texts/Articles/AustroLibertarianismAndTheCorporation.pdf

Voltaire (Arouet, F. M., dit) (1759). Candide ou l'optimisme. Paris: Eds de la Sirène.

von Hayek, F. A. (1960). The Constitution of Liberty. Chicago: University of Chicago Press.

von Mises, L. (1912). Theorie des Geldes und der Umlaufsmittel. München \& Leipzig: Duncker \& Humblot.

von Mises, L. (1996 [1949]. Human Action (4th ed.). San Francisco, CA: Fox \& Wilkes.

Whately, R. (1831). Introductory Lectures on Political Economy. London: B. Fellowes.

Zywicki, T. J. (2013). Libertarianism, Law and Economics, and the Common Law. Chapman Law Review, 16, 309-324. 